\title{
A Comparison of Old and Modern Type DNA Marker Technologies and Their Impact on Animal Breeding Programs
}

\author{
Zühal GÜNDÜZ1 ${ }^{1}$, Onur YILMAZ², İbrahim CEMAL², Osman BİÇER ${ }^{1}$
}

\begin{abstract}
In recent years, molecular genetic technologies allowed to identify genetic structure in farm animals have great advantages for animal breeding. Especially, in developed countries these methods began to be widely used to assist animal breeding studies. It can be said that there are various molecular genetic markers. These markers can be classified by taking into consideration a number of factors such as the principle of the detection technique, type of polymorphism. Although old type molecular genetic markers such as RFLP, AFLP, microsatellites are widely used today, the information obtained from them is more limited than modern molecular genetic markers. SNP chip technologies, which known as modern molecular markers and are one of the most important developments in the molecular genetics field, have provided genomic breeding value estimation and genomic selection in farm animals. In this review, old and new types of molecular markers were compared and their usage in animal breeding were discussed.
\end{abstract}

Keywords: Animal breeding, molecular markers, SNPs

\section{Eski ve Modern Tip DNA Marker Teknolojilerinin Karşılaştırılması ve Bunların Hayvan Islahı Programlarına Etkisi}

ÖZET: Son yıllarda, moleküler genetik teknolojiler hayvan ıslahı anlamında çiftlik hayvanlarının genetik yapısının tanımlanması için oldukça önemli avantajlar sağlamıştır. Özellikle gelişmiş ülkelerde bu yöntemler hayvan ıslahı çalışmalarında yaygın bir şekilde kullanılmaktadır. Çok fazla sayıda moleküler genetic işaretleyiciden bahsetmek mümkündür. Bu işaretleyiciler polimorfizm türü ve tarama tekniği gibi bir çok faktör dikkate alınarak sınıflandırılabilir. Eski tip moleküler genetik işaretleyiciler günümüzde yaygın olarak kullanılmasına rağmen bunlardan elde edilen moleküler bilgiler modern olanlara göre oldukça kısıtlıdır. Moleküler genetik alanda en önemli gelişmelerden olan ve modern genetik işaretleyici olarak bilinen SNP çip teknolojisi çiftlik hayvanlarında genomik damızlık değer tahminlerinin yapılmasına ve genomik seleksiyona olanak sağlamaktadır. Bu derlemede eski ve yeni tip moleküler işaretleyiciler karşılaştırılmış ve hayvan ıslahında kullanımları tartışılmıştır.

Anahtar Kelimeler: Hayvan 1slahı, moleküler işaretleyiciler, SNPs,

Mustafa Kemal Üniversitesi, Hayvan Yetiştirme ve Islahı A.B.D., Zootekni, Hatay, Türkiye

Adnan Menderes Üniversitesi, Biometri ve Genetik A.B.D., Zootekni, Aydın, Türkiye

Sorumlu yazar/Corresponding Author: Onur YILMAZ, oyilmaz@adu.edu.tr 


\section{INTRODUCTION}

Until recently, phenotypic selection or estimated breeding value (EBV) based on phenotype has been used for animal breeding to improve genetic progress for quantitative traits, without which genes affect the property or the effect of each loci (Walsh, 2000; Naqvi, 2007). Recent developments in molecular biology and statistics have prepared the opportunity of identifying and using genomic variation and QTL that affected the genetic improvement of livestock (Montaldo and MezaHerrera, 1998). Molecular markers have a significant role in animal breeding in terms of animal identification and to determine the genetic diversity by levels of DNA polymorphism. The increasing availability of molecular markers in farm animals such as cattle, sheep, goat, poultry and swine allows the detailed analyzes and evaluation of genetic diversity, and furthermore the detection of genes influencing economically important traits.

Although the majority of molecular markers used nowadays with high-throughput systems are microsatellite markers (simple tandem repeat, STR) and Single nucleotide polymorphisms (SNPs). Many molecular genetic markers such as random amplified polymorphic DNA (RAPD) markers, single-strand conformation polymorphisms (SSCPs), restriction fragment length polymorphisms (RFLPs) and amplified fragment length polymorphisms (AFLPs) markers are widely used in farm animals for the determination of genetic diversity, paternity analysis, detection of major genes and mapping of quantitative trait loci (QTL) (Kinghorn et al., 1993; Roher et al., 1994; Kinghorn 1997; Vignal et al., 2002).

The aim of this study was to discuss the comparison of molecular markers and its potential use in the animal breeding.

\section{DNA Marker Technologies and Their Use in Animal Breeding}

Litter size and production traits (milk, meat, wool etc.) in farm animals, considered as quantitative characters, are generally polygenic. These traits are influenced by many factors such as genes and environment. It has known that quantitative genetics approaches are important to increase the possibility of choosing the right animal to be parents (Nicholas, 1996). Molecular genetic techniques to identify the genetic structure and diversity in farm animals have shown rapid development in recent years and began to be widely used. Various molecular genetics marker technologies have been developed to reveal selection decision, genetic structure, and diversity.

\section{Older Types of Molecular Markers}

RAPDs (Random Amplification of Polymorphic DNA), AFLPs (Amplified Fragment Length Polymorphisms), SSCPs (Single Stranded Conformation Polymorphisms), RFLP (Restriction Fragment Length Polymorphisms) and microsatellites defined as the older type markers can be described in three main categories. They can be sorted as bi-allelic dominant (RAPDs, AFLPs), the bi-allelic co-dominant (RFLPs, SSCPs) and the multi-allelic codominant (microsatellites) (Vignal et al., 2002).

\section{Bi-allelic dominant markers (RAPDs, AFLPs)}

Although, use of RAPDs and AFLPs, described as dominant markers, do not seem that interesting to use at a first glance, they have great advantageous in terms of ease of use. RAPDs PCR technique, also known as APPCR (Arbitrarily Primed PCR), described by Williams et al., (1990) and Welsh et al., (1990), does not require any specific information of the DNA sequence for the targeted genome and is implemented using the randomized primers. The low reproducibility is one of the main disadvantages of RAPDs technique

RAPD technique is quite tightly dependent on the laboratory procedure therefore it must be very careful preparation of design of laboratory protocol.

Despite having a low-reliability method, RAPDs widely uses to identify genetic similarity and diversity, to measure inbreeding in population and the construction of genome map in farm animal (Rao et al., 1996; Bhattacharya et al., 2003; Ali, 2003; Ahmed, 2005; Binbaş, 2006; Elmaci et al., 2007; Kumar et al., 2008).

The amplified fragment length polymorphisms (AFLPs) technique, which is a cost-effective fingerprint technique and presents more information, is based on selective PCR amplification of a group of 
DNA fragments resulting from cutting with restriction enzyme. Hundreds of highly replicable markers from DNA of any organism are generated by this technique.

Amplified fragment length polymorphism (AFLP) technique allows for the identification of variations caused by SNP and indels which is very important for the identification of genetic diversity studies. For these reasons, this technique is widely used in genetic relationship studies, QTL analysis, linkage mapping, and profiling of gene expression using cDNA genetic diversity studies (Barendse et al., 1994; Otsen et al., 1996; Nijiman et al.,1999; Moreno et al., 2002; Foulley et al., 2006; Negrini et al., 2007).

Although, RAPDs and AFLPs markers are dominant and generated at random. Both of them are good choice for QTL mapping or diversity studies in species (Negrini et al., 2006).

\section{Bi-allelic co-dominant markers (RFLPs, SSCPs)}

Restriction Fragment Lenght Polymorphisms (RFLP) technique was developed following the discovery of restriction endonucleases in the 1960s. A simple and useful way of testing for a mutation is RFLP analysis, uses an enzyme with a recognition sequence created by the mutation (Simm, 1998). There are approximately more than 300 restriction enzymes that are isolated from bacteria and cut DNA wherever specific short sequences (Montaldo and Meza-Herrera 1998; Babalola, 2003). PCR-RFLP technique described just a polymorphism with each probe, is cheap and widely used more than another marker system such as RAPD, SSCP. This method is commonly used in nucleic acid hybridization definition, identification and diagnosis, description of polymorphisms on the gene construction of a genetic linkage map and recombinant DNA technology in farm animals (Solak et al., 2000; Vignal et al, 2002; Schlötterer, 2004; Turner et al., 2004; Cemal et al., 2009; Sevim et al., 2012; Yilmaz et al., 2013; Yilmaz et al., 2014).

The principle of Single-strand conformation polymorphism (SSCP) analysis based on PCR is a method used to separate DNA fragments of the same size. DNA polymorphisms and mutations at multiple regions in the single loci can be detected by SSCP as a mutation scanning technique (Orita et al., 1989; Bastas et al., 2001). Denaturing high-performance liquid chromatography (DHPLC) known as improved model of the SSCP technique is used for the separation of the heteroduplex and homoduplex strands (Liu et al., 1998). Reported results from SSCP studies are always particular to specific fragments and sequence changes; generalizations can be problematic. Mutations that show no mobility shift under one set of conditions may be revealed under different conditions (Hayashi, 1991; Fan et al., 1993; Sheffield et al., 1993). SSCPs uses to detect sequence variations, and screening of mutation in farm animal.

\section{Multi-allelic \\ codominant \\ markers (Microsatellites)}

Microsatellites markers, which are among the most widely used molecular genetic methods, are short tandemly repeated DNA sequences that are present in variable copy numbers at each locus and throughout the genome (Ashley and Dow, 1994; Forbes et al., 1995; Bruford et al.,1996; Ellegren et al.,1997; Montaldo and Meza-Herrera, 1998; Schlötterer, 1998; Schmid et al., 1999; Toth et al., 2000; Beuzen et al., 2000; Hancock, 2001;).

Microsatellites, which had spread a whole genome, are DNA sequences consisting of short repeats of highly variable number. Microsatellites have several advantageous such as highly polymorphic, co-dominant inheritance, easy genotyping and scored. For this reason microsatellite markers are widely used in genetic diversity and paternity analysis studies. (Bruford et al, 1996; Montaldo and Meza-Herrera, 1998; Beuzen et al.; 2000; Sancristobal et al, 2003; Schlötterer, 2004; Togan et al., 2005; Acar, 2010; Jyotsana et al., 2010; Arora et al., 2011; Kusza et al., 2011; Lasagna et al., 2011; Agaviezor et al., 2012; Alvarez et al., 2012; Yilmaz and Karaca, 2012; Cemal et al., 2013; Yilmaz et al., 2013, Öner et al. 2014; Yilmaz et al. 2014).

\section{Modern Types of Molecular Marker}

New genetic technologies developed rapidly have found applications in animal production. Identification of gene regions with an effect on complex quantitative traits of economic importance will increase genetic gain and its proportion per year. The SNPs genotyping technologies provide powerful resources for animal breeding programs. Genomic selection using SNPs is a new tool for choosing the best breeding animals. In 
addition, the high density maps using SNPs can provide useful genetic tools to study quantitative traits genetic variations (Koopaee and Koshkoiyeh, 2014; Y1lmaz et al., 2015).

\section{Single nucleotide polymorphisms (SNPs)}

Old type molecular markers were widely used to determine genetic diversity, paternity analysis and other molecular genetic studies in the last two decade. Nowadays, scientific studies have focused on singlenucleotide polymorphisms (SNPs) to identify genetic variations. SNP is defined single nucleotide changes in a specific base position that occurs in around $1 \%$ of a large population.

SNPs have emerged as a powerful tool in marker technology, was first proposed by Lander (1996), it refers to a sequence polymorphism caused by a single nucleotide mutation at a specific locus in the DNA sequence (Akey et al., 2001, Yang et al., 2013). SNPs, forming the $90 \%$ all of genetic variation, are the most modern method of genotyping with a greater sensitivity and ease of automation (Landegren et al., 1998). SNPs have low mutation rates and can be amplified easily for testing (Lipshutz et al., 1999; Beuzen et al., 2000; Stoneking, 2001; Vignal et. al., 2002).

SNPs provide convenience in genetic disease studies, paternity testing, traceability, estimation of genomic breeding values (GEBVs), genetic mapping for various livestock species. Today, genomic selection has become possible with determining millions SNP by a single analysis in various animal species (Hayes et al., 2007; Goddard and Hayes, 2007; Hayes et al.,2009; Bolormaa et al., 2010; Slack-Smith et al., 2010; Bolormaa et al., 2011; Daetwyler et al., 2012; Eggen, 2012)

\section{CONCLUSIONS}

Molecular markers have been developed and potential tools for animal breeding. Nowadays molecular genetic techniques, provided an important contribution to the quantitative theory, have become a vital tool for animal breeding program. Molecular markers are very important for the determination of genetic variation within and between populations, re-construction of pedigree data, measurement of the effective population size, identify admixture populations, providing of evolution history in population genetics.

In summary, for molecular techniques make a great benefaction to livestock production system we need a joined-up strategy addressing genetic progress as well as conservation, rather than gradually proceeding classical breeding methods.

\section{REFERENCES}

Acar H, 2010. Bioinformatic analyses in microsatellite-based genetic diversity of Turkish sheep breeds. Orta Doğu Teknik Üniversitesi, Fen Bilimleri Enstitüsü, Yüksek Lisans tezi, $147 \mathrm{~s}$.

Agaviezor BO, Peters SO, Adefenwa MA, Yakubu A, Adebambo OA, Ozoje MO, Ikeobi CO, Wheto M, Ajayi OO, Amusan SA, Ekundayo OJ, Sanni TM, Okpeku M, Onasanya GO, De Donato M, Ilori BM, Kizilkaya K, Imumorin IG, 2012. Morphological and microsatellite DNA diversity of Nigerian indigenous sheep. Journal of Animal Science and Biotechnology, 3(1): 38.

Ahmed MMM, 2005. Species identification in meat origin farm animals through DNA technology. Biotechnology in Animal Husbandry, 21(1-2):13-24.

Akey JM, Sosnoski D, Parra E, Dios S, Hiester K, Su B, Bonilla C, Jin L, Shriver MD, 2001. Melting Curve Analysis of SNPs (McSNP): A Gel-Free and Inexpensive Approach for SNP Genotyping. BioTechniques 30:358-367

Ali BA, 2003. Genetics similarity among four breeds of sheep in Egypt detected by random amplified polymorphic DNA markers. African Journal of Biotechnology, 2(7): 194-197.

Alvarez I, Capote J, Traore A, Fonseca N, Pérez K, Cuervo M, Fernandez I, Goyache F, 2012. Genetic relationships of the Cuban hair sheep inferred from microsatellite polymorphism. Small Ruminant Research, 104(1-3): 89-93.

Arora RJ, Bhatia S, Mishra BP, Jain A, Prakash B, 2011. Diversity analysis of sheep breeds from Southern peninsular and Eastern regions of India. Tropical Animal Health and Production, 43(2):401-408.

Ashley MV, Dow BD, 1994. The use of microsatellite analysis in population biology: Background, methods and potential applications. Editors: Schierwater B, Streit B, Wagner GP, desalle R Boston. Birkhauser Verlag. Pp. 185-202.

Babalola OO, 2003. Molecular techniques: an overview of methods for the detection of bacteria. African Journal of Biotechnology, 2(12): 710-713.

Barendse W, Armitage SM, Kossarek LM, Shalom A, Kirkpatrick BW, Ryan AM, Clayton D, Li L, Neibergs HL, Zhang N, Grosse WM, Weiss J, Creighton P, McCarthy F, Ron M, Teale AJ, Fries R, McGraw RA, Moore SS, Georges M, Soller M, Womack JE, Hetzel DJS, 1994. A genetic linkage map of the bovine genome. Nature Genetics, 136:619-639.

Bastas E, Cravador A, Azevedo J, Guedes-Pinto H, 2001. Single strand conformation polymorphism (SSCP) detection in six genes in Porteguse indigenous sheep breed Cherra da Terra Quente. Biotechnology, Agronomy, Society and Environment, 5(1):7-15. 
Beuzen ND, Stear MJ, Chang KC, 2000. Molecular markers and their use in animal breeding. The Veterinary Journal, 160: 4252.

Bhattacharya TK, Kumar P, Joshi JD, Kumar S, 2003. Estimation of inbreeding in cattle using RAPD markers. Journal of Dairy Research, 70:127-129.

Binbaş P, 2006. Çine çaparı koyunlarda genetik çeşitliliğin RAPD yöntemi ile belirlenmesi. Adnan Menderes Üniversitesi, Fen Bilimleri Enstitüsü, Yüksek Lisans tezi, 62s.

Bolormaa S, Pryce JE, Hayes BJ, Goddard ME, 2010. Multivariate analysis of a genomewide association study in dairy cattle. Journal of Dairy Science, 93:3818-3833.

Bolormaa S, Porto Neto LR, Zhang YD, Bunch RJ, Harrison BE, Goddard ME, Barendse W, 2011. A genome -wide association study of meat and carcass traits in australian cattle. Journal of Animal Science, 89:2297-309.

Bruford MW, Chessman DJ, Coote T, Gren HAA, Haines SA, O'Ryan C, Williams TR, 1996. Microsatelites and their application to conservation genetics. Molecular Genetic Approaches in Conservation. Oxford University Press. U.K. 278-297p.

Cemal I, Karaca O, Davis GM, Galloway SM, Yilmaz O, 2009. Molecular genetic testing of Karya sheep for Booroola and Inverdale mutations. International Scientific Conference (BALNIMALCON- 2009): Challenges of the Balkan Animal Industry and the Role of Science and Cooperation. May 14-16, 2009, Trakia University Stara Zagora - Bulgaria, 108-111 p.

Cemal I, Yilmaz O, Karaca O, Binbaş P, Ata N, 2013. Analysis of genetic diversity in indigenous Çine Çaparı sheep under conservation by microsatellite markers. Journal of the Faculty of Veterinary Medicine, Kafkas University, 19:383-90.

Daetwyler HD, Swan AA, Van Der Werf JHJ, Hayes BJ, 2012. Accuracy of pedigree and genomic predictions of carcass and novel meat quality traits in multi-breed sheep data assessed by cross-validation. Genetics Selection Evolution, 33-44.

Eggen A, 2012. The development and application of genomic selection as a new breeding paradigm. Animal Frontiers, 2(1): $10-15$.

Elmaci C, Öner Y, Ozis S, Tuncel E, 2007. RAPD analysis of DNA polymorphism in Turkish sheep breeds. Biochemical Genetics, 45(9-10):691-696.

Ellegren H, Moore S, Robinson N, Byrne K, Word W, Sheldons BC, 1997. Microsatellite evolution a reciprocal study of repeated lengths at homologous loci in cattle and sheep. Molecular Biology of Evolution, 14(8): 854-60.

Fan E, Levin DB, Glickman BW, Logan DM, 1993. Limitations in the use of SSCP analysis. Mutation Research, 288:85-92.

Foulley JL, Van Schriek MGM, Alderson L, Amigues Y, Bagga M, Boscher MY, Brugmans B, Cardellino R, Davoli R, Delgado JV, Fimland E, Gandini GC, Glodek P, Groenen MAM, Hammond K, Harlizius B, Heuven H, Joosten R, Martinez AM, Matassino D, Meyer JN, Peleman J, Ramos AM, Rattink AP, Russo V, Siggens KW, Vega-Pla, JL, Ollivier L, 2006. Genetic diversity analysis using lowly polymorphic dominant markers: The example of AFLP in pigs. Journal of Heredity, 97(3):244-252.

Forbes SH, Hogg JT, Buchanan FC, Crawford AM, Allendorf FW, 1995. Microsatellite evolution in congeneric mammals, domestic and Bighorn sheep. Molecular Biology and Evolution, 12(6):1106-1113.
Goddard ME, Hayes BJ, 2007. Genomic selection. Journal of Anim Breeding and Genetics, 124(6):323-330.

Hancock JM, 2001. Microsatellites and other simple sequences: genomic context and mutational mechanisms. Microsatellites evolution and application. Editors: Goldstein, D.B., Schlötterer, C. U.K.: Oxford University Press

Hayashi K, 1991. PCR-SSCP: A simple and sensitive method for detection of mutations in genomic DNA. PCR Methods and Application, 1: 34-38.

Hayes B.J. 2007. QTL Mapping, MAS and Genomic Selection.A Shorth-Course Organized by Animal Breeding of Animal Science Iowa State University, USA.

Hayes BJ, Bowman PJ, Chamberlain AJ, Goddard ME, 2009. Invited Review: Genomic Selection in Dairy Cattle: Progress and Challenges. Journal of Dairy Science, 92:433-443.

Jyotsana B, Jakhesara S, Prakash V, Rank DN, Vataliya PH, 2010. Genetic features of Patanwadi, Marwari and Dumba sheep breeds (India) inferred by microsatellite markers. Small Ruminant Research, 93(1):57-60.

Lander ES, 1996. The new genomics: global views of biology. Science, 274:536-539.

Kinghorn BP, Kennedy BW, Smith C, 1993. A method for screening for genes of major effect. Genetics, 134:351-360.

Kinghorn BP, 1997. An index of information content for genotype probabilities derived from segregation analysis. Genetics, 145:479-483.

Koopaee HK, Koshkoiyeh, AE, 2014. SNPs genotyping technologies and their applications in farm animals breeding programs: review. Brazilian Archives of Biology and Technology, 57(1): 87-95.

Kumar S, Kolte AP, Yadav BR, Kumar S, Arora AL, Singh VK, 2008. Genetic variability among sheep breeds by random amplified polymorphic DNA-PCR. Indian Journal of Biotechnology, 7:482-486.

Kusza S, Ivankovic A, Ramljak J, Nagy I, Javor A, Kukovics S, 2011. Genetic structure of Tsigai, Ruda, Pramenka and other local sheep in Southern and Eastern Europe. Small Ruminant Research, 99(2-3): 130-134.

Landegren U, Nilsson M, Kwok PY, 1998. Reading bits of genetic information: Methods for single-nucleotide polymorphism analysis. Genome Research, 8:769-776.

Lasagna E, Bianchi M, Ceccobelli S, Landi V, Martínez AM, Pla JLV, Panella F, Bermejo JVD, Sarti FM, 2011. Genetic relationships and population structure in three Italian Merino-derived sheep breeds. Small Ruminant Reserach,96:111-119.

Lipshutz RJ, Fodor SPA, Gingeras TR, Lockhart DJ, 1999. High density synthetic oligonucleotide arrays. Nature Genetics, 21(supp. 1): 20-24.

Liu W, Smith DI, Rechtzigel KJ, Thibodeau SN, James CD, 1998. Denaturing high performance liquid chromatography (DHPLC) used in the detection of germline and somatic mutations, Nucleic Acids Reserach, 26:1396-1400.

Montaldo HH, Meza-Herrera CA, 1998. Use of molecular markers and major genes in the genetic imrovement of livestock. Electronic Journal of Biotechnology, 1(2): 83-89.

Moreno Y, Ferrus AM, Vanoostende A, Hernandez J, Montes MR, Hernandez J, 2002. Comparison of $23 \mathrm{~S}$ polymerase chain reaction-restriction fragment length polymorphism techniques 
as typing systems for thermophilic campylobacters. FEMS Microbiology Letters, 211:97-103.

Naqvi AN, 2007. Applications of molecular genetic technologies in livestock production: Potentials for developing countries. Advances in Biological Research, 1(3-4) :72-84.

Negrini R, Milanesi E, Bozzi R, Pellecchia M, Ajmone-Marsan P, 2006. Tuscany autochthonous cattle breeds: an original genetic resource investigated by AFLP markers. Journal of Animal Breeding and Genetics, 123:10-16.

Negrini R, Nijman IJ, Milanesi E, Moazami-Goudarzi K, Williams JL, Erhardt G, Dunner S, Rodellar C, Valentini A, Bradley DG, Olsaker I, Kantanen J, Ajmone-Marsan P, Lenstra JA, the European Cattle Genetic Diversity Consortium, 2007. Differentiation of European cattle by AFLP fingerprinting Animal Genetics, 38: 60-66.

Nicholas FW, 1996. Introduction to veterinary genetics. Oxford University Press, New York 64-65.

Nijiman IJ, Bladley DG, Hannotte O, Otsen M, Lenstra JA, 1999. Satellite DNA polymorphisms and AFLP correlate with Bos indicus-taurus hybridization. Animal Genetics, 30:265-273.

Oner Y, Üstüner H, Orman A, Y1lmaz O, Y1lmaz A, 2014. Genetic diversity of Kivircik sheep breed reared in different regions and their relationship to other sheep breeds in Turkey. Italian Journal of Animal Science, 13:588-593.

Orita M, Iwahana H, Knazawa H, Hayashi K, Sekiya T, 1989. Detection of the polymorphisms of human DNA by gelelectrophoresis as single-strand conformation polymorphisms. Proceedings of the National Academy of Sciences, 86:2766-2770.

Otsen M, Denbieman M, Kuiper MTR, Pravenec M, Kren V, Kurtz TW, Jacob HJ, Lankhorst AE, Vanzutphen BFM, 1996. Use of AFLP markers for gene mapping and QTL detection in the rat. Genomics, 37:289-294.

Rao AKBC, Bhat KV, Totey SM, 1996. Detection of species-specific genetic markers in farm animals through random amplified polymorphic DNA (RAPD). Genetic Analysis: Biomolecular Engineering, 13(5):135-138.

Rohrer GA, Alexander LJ, Keele JW, Smith TP, Beattie CW, 1994. A microsatellite linkage map of the porcine genome. Genetics, 136(1):231-245.

Sancristobal M, Chevalet C, Foulley JL, Ollivier L, 2003. Some methods for analysing genetic marker data in biodiversity setting example of the Pigbiodiv data. Archivos de Zootecnia, 52:173-183.

Schlötterer C, 1998. Genome evolution: Are microsatellites really simple sequences? Current Biology, 8:132-134.

Schlötterer C, 2004. The evolution of molecular markers just a matter of fashion. Nature Reviews Genetics, 5:63-69.

Schmid M, Saitbekova N, Gaillard C, Dolf G, 1999. Genetic diversity in Swiss cattle breeds. Journal of Animal Breeding and Genetics, 116(1):1-8.

Sevim S, Yilmaz O, Karaca O, Cemal I, 2012. Mastitis resistance genes in dairy cattle. International Animal Science Congress of Turkish and Relatives Communities, September 11-13, 2012, Isparta.

Sheffield VC, Beck JS, Kwitek AE, Sandstrom DW, Stone EM, 1993. The sensitivity of single-strand conformation polymorphism analysis for the detection of single base substitutions. Genomics, 16: 325-332.
Simm G, 1998. Genetic improvement of Cattle and Sheep. Farming Pres United Kingdom.

Slack-Smith A, Kingorhn BP, Hickey JM, Van Der Werf JHJ, 2010. The Accuracy of Genomic Selection in Predicting Carcass Traits in Meat Sheep. 9th World Congress on Genetics Applied to Livestock Production in Leipzig, Germany.

Stoneking M, 2001. Single nucleotide polymorphisms: From the evolutionary past. Nature, 409: 821-822.

Solak M, Bağcı H, Şengil AZ, Öztaş S, 2000. Moleküler genetik ve rekombinant DNA teknolojisi (Temel İlkeler). Afyon Kocatepe Üniversitesi Eğitim, Sağlık ve Bilimsel Araştırmalar Vakf Yay No: 5, Ankara.

Togan İ, Soysal İ, Berkman CC, Koban E, 2005. Irkların korunmasında moleküler işaretler. NKU Ziraat Fakültesi Dergisi, 2(1):44-49.

Toth G, Gaspari Z, Jurka J, 2000. Microsatellites in different eukaryotic genomes: Survey and Analysis. Genome Research, 10(7): 967-81.

Turner PC, Mclennan AG, Bates AD, White MRH, 2004. Moleküler Biyoloji (önemli notlar) (Çev. Ed. Muhsin Konuk). Nobel yay. No:613, Ankara.

Vignal A, Milan D, Sancristobal M, Eggen A, 2002. A review on Snp and other types of molecular markers and their use in animal genetics. Genetic Seleciton and Evolution, 34:275-305.

Yang W, Kang X, Yang Q, Lin Y, Fang M, 2013. Review on the development of genotyping methods for assessing farm animal diversity. J Anim Sci Biotechnol, 4(1): 2.

Williams JGK, Kubelik AR, Livak KJ, Rafalski JA, Tingey SV, 1990. DNA polimorphism amplified by arbitrary primers are useful as genetic markers. Nucleic Acids Research, 18:65316535.

Welsh J, Mcclelland M, 1990. Fingerprinting Genomes Using PCR With Arbitrary Primers. Nucleic Acids Research, 18:72137218.

Walsh B, 2000. Minireview: Quantitative genetics in the age of genomics. Theoretical Population Biology, 59:175-184.

Yilmaz O, Karaca O, 2012. "Paternity Analysis with Microsatellite Markers in Karya Sheep", Journal of the the Faculty of Veterinary Medicine, Kafkas University, 18(5):807-813.

Yilmaz O, Cemal I, Karaca O, Ata N, Sevim S, Ozturk M, 2013. Genetic diversity of Karya and Çine Çapari sheep. Scientific Papers. Series D. Animal Science, LVI: 31-35.

Yilmaz O, Cemal İ, Karaca O, 2014. Genetic diversity in nine native Turkish sheep breeds based on microsatellite analysis. Animal Genetics, 45 (4): 604-608.

Y1lmaz O, Öner Y, Karaman E, Cemal İ, 2015. Çiftlik hayvanlarında genom boyu ilişki analizleri ve genomik seleksiyon. 9. Ulusal Zootekni Bilim Kongresi. 3-5 Eylül 2015, Konya. 